\title{
Localization and Corruption: Panacea or Pandoras Box?
}

\author{
Tugrul Gurgur \\ World Bank \\ and \\ Anwar Shah* \\ World Bank \\ E-mail: ashah@worldbank.org
}

\begin{abstract}
An extensive literature on the relationship between decentralization (or localization) and corruption has developed in recent years. While some authors argue that there is a positive relationship between decentralization and corruption, others claim that decentralization in fact leads to a reduction in the level of corruption. This important policy question has not yet been laid to rest, since previous empirical work simply uses eclectic regressions and lacks a conceptual framework to discover the root causes of corruption. This paper attempts to fill this void by presenting a framework in identifying the drivers of corruption both conceptually and empirically in order to isolate the role of centralized decision-making on corruption. The following results emerge:

- For a sample of 30 countries (developing and industrial), corruption is caused by: a lack of service-orientation in the public sector, weak democratic institutions, economic isolation (closed economy), colonial past, internal bureaucratic controls and centralized decision making.

- Decentralization is found to have a negative impact on corruption, with the effect being stronger in unitary than in federal countries.
\end{abstract}

Key Words:

JEL Classification Numbers:

\section{INTRODUCTION}

A large and growing number of countries around the globe are re-examining the roles of various levels of government and their partnership with the

\footnotetext{
* The authors are grateful to participants at the IMF Conference on Managing Fiscal Decentralization especially Vito Tanzi and Ehtisham Ahmad and John Macgregor and Theresa Thompson for comments and for various background materials for this paper.
}

109 
private sector and the civil society with a view to creating governments that work and serve their people (see Shah, 1998 for motivations for such a change). The overall thrust of these changes manifest a trend toward either devolution (empowering people) and/or localization (decentralization). Localization has been pursued through varying combinations of political, administrative and fiscal decentralization initiatives. Political or democratic decentralization implies directly elected local governments (thereby making elected officials accountable to citizens). Administrative decentralization empowers these governments to hire and fire local staff (thereby making local officials accountable to elected officials) without any reference to higher level governments and fiscal decentralization entrusts these governments with fiscal autonomy in their spheres of taxing and spending responsibilities. Fiscal decentralization ensures that elected officials weigh carefully the joys of spending someone else's money as well as pains associated with raising revenues from the electorate and facing the possibility of being voted out of office.

Administrative deconcentration, where decision-making is shifted to regional and local offices of the central government, would not be consistent with this view of administrative decentralization. Thus, localization of authority is intended to bring decision-making closer to the people being served by the public sector. This change has proved to be a controversial proposition. This is because localization is perceived both as a solution to problems, such as a dysfunctional public sector, lack of voice and exit, as well as a source of new problems, such as capture by local elite, aggravation of macroeconomic management due to lack of fiscal discipline and perverse fiscal behavior by sub-national units. ${ }^{1}$ There are also conceptual difficulties in making choices on the right balance as discussed in Shah (1994) and Boadway, Roberts and Shah (2000). The impact of localization on corruption (defined as the abuse of public office for private gain or exercise of official powers against public interest) is an area of growing interest inviting much controversy and debate. However, much of the discussion is grounded in selective anecdotal evidence. This paper provides a synthesis and strengthens the empirical foundations of this debate by examining the causes of corruption and trying to isolate the role of centralized decision making in creating an enabling environment for an accountable public sector.

\footnotetext{
${ }^{1}$ See Tanzi (1995) and Shah (1998) for opposing views.
} 


\section{LOCALIZATION AND CORRUPTION: A PANDORA'S BOX PERSPECTIVE}

The promise of localization to bring accountability is considered hollow and such efforts are instead viewed as counterproductive in curtailing corruption by Tanzi (1995), who argues that localization brings officials in close contact with citizens. This promotes personalism and reduces professionalism and arms-length relationships. Personalism in his view breeds corruption as officials pay greater attention to individual citizen needs and disregard public interest. Prudhomme (1995) supports this view and argues that incidence of corruption is expected to increase with localization for several reasons. Opportunities for corruption increase due to a greater influence of interest groups at the local level, greater discretion available to local officials and long tenure of local officials at the same place making it easier to establish unethical relationships. Impediments to corrupt practices also decrease as local politicians and bureaucrats collude to advance narrow self-interests while the influence of media and auditing agencies wanes. Treisman $(1999,2000)$, using cross-country regression analysis, lends further support to this view, arguing that federal systems tend to have higher corruption ratings due to (a) their larger size; (b) their being more likely to have separate police forces at both central and subnational levels (which increases corruption due to overgrazing) and (c) their greater propensity to have a regionally elected upper house of parliament with veto power (which also may increase corruption as regional governments may buy off these veto-players or have greater leverage to protect their ill-gotten gains).

Political decentralization is seen as a source of corruption in Russia but not China by Blanchard and Shleifer (2000). This conclusion emerges from the contrasting role of local governments in their relations with local enterprises observed in China and Russia. In China, local governments have provided a supporting role whereas in Russia, local governments have stymied the growth of new firms through taxation, regulation and corruption. The authors note that the behavior of Russian local governments can be explained by (a) state capture by old firms, leading local governments to protect them from competition and (b) rent seeking behavior of local officials discouraging new firms to enter. The authors attribute this contrasting experience to the presence of political decentralization in Russia and its absence in China. They argue that political centralization in China contributes to party discipline, which in turn reduces the risk of local capture and corruption.

While Tanzi and Prudhomme simply present personal perspectives on this issue, Triesman resorts to empirical evidence to show that localization represents a Pandoras box in fighting corruption. Treismans empirical re- 
sults however are sensitive to the inclusion of other variables in the equation and may have omitted variables bias in view of the lack of an underlying framework for corruption. ${ }^{2}$ The Blanchard-Shleifer analysis does not pay sufficient attention to local-enterprise relations in the two countries. Local enterprises in China are owned and run by local governments and even deliver local services such as education, health and transportation in addition to their economic functions. Thus local enterprises are part and parcel of the local government. In Russia, on the other hand, a mixed pattern of these relationships has begun to emerge. Therefore, the contrasting experience of the local governments may better be explained by agency problems rather than by political decentralization. In fact the weakening of party discipline through the emergence of powerful local leaders may be contributing to the growth of local industry as the strong arm of central planning is held at bay by these leaders. In conclusion, the perception of localization as a "Pandoras Box" is grounded in neither theory nor evidence.

\section{LOCALIZATION AND CORRUPTION: A PANACEA?}

There is a general agreement in the literature that localization can open up greater opportunities for voice and choice thereby making the public sector more responsive and accountable to citizens-voters. Competition among local governments for mobile factors re-enforces the accountability culture. Such enhanced accountability has the potential to reduce corruption. Seabright (1996) argues that accountability is always better at the local level, since local citizens who are better informed about government performance can vote these governments out of office. Under centralization, people vote for parties or candidates partly on the basis of performance in other regions and on issues of national interest. As a result accountability is defused and potential for corruption increases. Bardhan and Mookherjee (2000) also argue that decentralization of the delivery of antipoverty programs in developing countries promotes cost-effectiveness and reduces corruption, owing to the superior access of local governments to information on local costs and needs.

Administrative decentralization results in a reduction in the amount of control that higher-level governments have over lower-level administrations, curbing the incentives of higher-level officials to monitor and detect corrupt activities. However, it also lowers the expected gains from corruption since, following decentralization, the number of individuals who are in charge of a single decision is reduced. It is then more likely that corrupt agents are called to bear the consequences of their actions. Hence Carbonara (2000) concludes that decentralization although creating agency problems inside

${ }^{2}$ For a critique of Treisman see Lambsdorff (1999). 
an organization can help in controlling corruption. Wildasin (1995) also argues that local officials with limited powers have little scope to engage in massive corruption.

Based upon a conceptual model, Ahlin (2000) argues that deconcentration has the potential to increase corruption, whereas political decentralization has the potential to contain it due to interjurisdictional competition.

A number of empirical studies also provide support for the positive influence of localization in controlling corruption. Crook and Manor (2000) examined the process of political decentralization in India (Karnataka state), Bangladesh, Cote dIvoire and Ghana and find that such decentralization leads to enhanced transparency. With this enhanced transparency, ordinary citizens become better aware of governments successes and failures and they may perceive the government institutions more corrupt than the perception they had before. They observed that in Karnataka, India, political decentralization substantially reduced the amount of public funds diverted by powerful individuals. However, since citizens were not aware of these diversions, they concluded that corruption had increased. Crook and Manor based upon evidence from Karnataka conclude that political decentralization reduces grand theft but increases petty corruption in the short run but in the long run both may go down. Olowu (1993) also considers political centralization as a root cause of endemic corruption in Africa. Fiszbein (1997) based upon a review of political decentralization in Colombia concludes that competition for political office opened the door for responsible and innovative leadership that in turn became the driving force behind capacity building, improved service delivery and reduced corruption at the local level.

A few studies show that administrative decentralization reduces corruption. Wade (1997) finds that over-centralized top down management accompanied by weak communication and monitoring systems contributes to corruption and poor delivery performance for canal irrigation in India. Kuncoro (2000) finds that with administrative decentralization in Indonesia, firms relocated to areas with lower bribes.

Increased fiscal decentralization is also shown to be associated with enhanced quality of governance as measured by citizen participation, political and bureaucratic accountability, social justice, improved economic management and reduced corruption by Huther and Shah (1998).

Thus, a small body of theoretical and empirical literature (for a survey of this literature, see Shah, Thompson and Zou, 2004) confirms that localization offers significant potential in bringing greater accountability and responsiveness to the public sector at the local level and reducing the incidence of grand corruption. However, a systemic examination of the root causes of corruption is not available, and hence the results from the literature must be seen as tentative and subject to further scrutiny. 


\section{THE CAUSES OF CORRUPTION: A CONCEPTUAL FRAMEWORK}

The economic analysis of the determinants of corruption has typically drawn upon either Beckers "crime and punishment" model or principal agent theory. ${ }^{3}$ The first one focuses on an individual who compares the expected utilities of legal and illegal behavior, where the latter involves some probability of detection and punishment. Fundamental propositions of this model are that the incidence of illegal behavior is positively related to the potential gains from illegal activity and negatively related to the probability of conviction and the punishment. In Beckers framework gains from legal activities are explicitly defined as the government wage, promotion, and public pension, whereas potential gains from corrupt behavior are assumed to be a function of variables describing the size and scope of the public sector. The more governments intervene in the operation of markets, the more opportunities for corruption appear through discretion on regulations and allocation of resources. Since "corruption is a sale of government property by government officials", bigger governments allow corrupt officials to discover and auction more profitable parts of the government. On the other hand, institutions of accountability are pictured as mechanisms that lead to detection and punishment of offenders. Although these institutions are limited to the judiciary in Beckers model, they can also be extended to political institutions and civil society as well.

The principal-agent models, such as Rose-Ackerman (1978) and Klitgaard (1988), regard corruption as an information problem on behalf of the "principal" who fails to control the "agent" properly. In this context, the citizens who elect a politician are considered as the principals and the politician as the agent - or the top level of government as the principal and government officials as the agents. These models primarily rely on information problems in explaining the incidence of corruption. The monopoly power of officials and the degree of discretion they enjoy in exercising this power create a formidable information barrier between the principal and the agent. Not surprisingly these models heavily emphasize the importance of monitoring the power of institutions and horizontal competition within the government as an antidote to corruption. The classic principal-agent framework has been extended to include chains of principal-agent relationships exploring various aspects of private organizations with possible collusion among the members (see Tirole, 1986 and Laffont, 1990).

\subsection{A Synthesis}

There is little difference between the crime-and-punishment model and the principal agent model in explaining corruption. In both models corrup-

${ }^{3}$ See Becker (1968), Becker and Stigler (1974), Huther and Shah (2000). 
tion is regarded as a function of two major sets of variables: opportunities for corruption and controlling power of institutions. The first set covers a wide range of variables from the size of government to state intervention to the economy. Government wage and remuneration practices also belong to this category. The second captures various institutions such as internal control mechanisms, judiciary, political institutions, and civil society.

\subsection{The State in the Economy}

A country characterized by heavy government involvement is more likely to encounter corruption. Since government has the authority to redistribute resources and rents in the economy, this authority can be used for personal gains. Government officials can benefit from their monopoly power and administrative discretion by extracting bribes from those that need the authorizations or permits to engage in activities. These officials may refuse authorization for new investments, delay paperwork for import permits, use safety standards as an excuse to close down businesses, give different meanings to economic regulations to turn down foreign exchange or bank credit requests, and so on. In the presence of restrictions on imports of certain goods, the necessary import licenses become very valuable and importers may be willing to bribe the relevant official to obtain them. On the other hand, an open economy reduces the level of available rents, which in turn leads to a reduction in the amount of corruption in the economy.

Similarly, protection schemes generate rents that local firms are willing to pay for. The size of government spending, the procedure used in allocating expenditures or selecting investment projects, and active participation in the economy also affect the opportunities for corruption. Government consumption expenditures and government-operated enterprises involve the substitution of political coercion for market choice and coordination. The size of government spending, transfer payments and subsidies, and the procedures used in allocating expenditures or selecting investment projects constitute sources of rents and corruption. High tax rates and complex tax regulations may be used by corrupt tax officials to collect bribes in exchange for alleviating tax burdens of taxpayers.

Evidence from empirical research suggests that participation of government in the economy through state-owned enterprises, active industrial policies, restrictive trade and exchange regimes, price and interest rate controls, excessive regulations, and complex tax systems are all associated with higher corruption. ${ }^{4}$ Usually it is the scope of government activities, not the size of government that affects the incidence of corruption. ${ }^{5}$

\footnotetext{
${ }^{4}$ See Ades and Di Tella (1997), Van Rickeghem and Weder (1997), Treisman (2000) and Johnson et al (1998).

${ }^{5}$ Goel and Nelson (1998).
} 


\subsection{Recruitment, Enumeration, and Government Pay}

A satisfactory level of government pay, merit-based recruitment and enumeration, and adequate pensions may constitute powerful incentives not to engage in corruption. When officials are poorly paid, they may try to supplement their pay with bribery. In many countries wage reductions have coincided with declines in the efficiency of the public sector, epidemic corruption, and deterioration in revenue performance of governments (Van Rickeghem and Weder, 1997). Similarly, the lack of meritocratic recruitment and promotion and absence of professional training are also found to be associated with high corruption (see Evans and Rauch, 1997).

\subsection{Internal Control Mechanisms}

Rules of conduct and administrative laws are designed to define the operations of government, such as procedures on public procurement and selecting private firms for contracting. Special agencies within the administration are formed to oversee implementation these rules. However, where corruption is systemic, the formal rules are usually superseded by informal rules. Patron-client relationships in bureaucracy undermine the effectiveness of internal monitoring. Especially when the corruption is triggered by senior officials and politicians, internal control agencies lose their organizational purpose and become demoralized.

\subsection{Judiciary}

An independent, impartial and informed judiciary has a central role in reviewing actions taken by the government and public officials. Enforcing the rule of law requires a strong, independent, and responsible judiciary, investigative and auditing bodies, and legitimate access to the society. In some cases, governments can influence the judicial system, using covert punishment threats, e.g., appointments to less attractive locations in distant parts of the country, or can completely ignore court decisions. Criminal law is usually too blunt an instrument to deal with corruption in the public service. Judicial institutions may operate too slowly or existing laws may not be well defined to deter corruption. Empirical evidence shows that an effective judiciary is a significant element of anti-corruption efforts. ${ }^{6}$

\subsection{Political Institutions}

In the political arena government operations are monitored by the parliament, and most importantly by parliamentary committees. Although the jurisdictions of the parliament and committees are usually quite extensive, partisan preferences of members and the lack of resources prevent adequate oversight of government. Moreover, the executive branch can escape from

\footnotetext{
${ }^{6}$ See Ades and Di Tella (1997), Van Rickeghem and Weder (1997), Goel and Nelson (1998) and Treisman (2000).
} 
parliamentary oversight, if the parliament is controlled by the parties in government.

\subsection{Civil Society}

A full set of formally democratic institutions will not produce accountable government, without a strong civil society, which enables social groups - trade and professional associations, community groups - to function as "whistle-blowers". Although formal institutions have more power and authority to address the incidence of corruption, the importance of informal institutions and civil society should not be underestimated. Neither internal control mechanisms nor the judiciary is immune to corruption, and more importantly they often need incentives to function properly. An independent and self-motivated press, responsive opposition groups and wellestablished non-governmental organizations can express themselves given that civil liberties exist to secure free access to government operations. In many empirical studies political and civil rights are found to have a positive impact on governance. ${ }^{7}$

\section{FROM THEORY TO PRACTICE: WHAT IS MISSING?}

So far we have seen the traditional approach to corruption in government. However, this approach fails to explain widespread corruption in many developing countries. Contrary to the principal-agent models, corrupt practices are not necessarily unknown to the society ("the principal") in most cases. Although the identities of corrupt officials as well as their activities are well known, institutions are not well developed to enforce the rule of law and to punish the disobedient. Similarly, crime-and-punishment models also perform a poor job in explaining why some officials choose illegal behavior over legal ones although they do not need additional compensation to support their living. If the marginal gain from corruption is still high enough to exceed the marginal cost of being caught, this means that probability of punishment and/or penalties are not only far from being deterrent, but also formal rules have been superseded by informal ones, which create an elite class in government immune from formal control.

One explanation for ineffective institutions and pervasive behavior of government officials can be found in the social and bureaucratic culture of the society. Leff (1964) argues that a culture of bureaucratic elitism may lead to a dissociation of civil servants from the rest of the society and breed corruption. In many countries, the bureaucracy is separated from society to such an extent that the state apparatus becomes an end itself, not an

\footnotetext{
${ }^{7}$ See Ades and Di Tella (1997), Van Rickeghem and Weder (1997), Johnson, Kaufmann and Zoido-Lobaton (1998), Isham, Kaufmann and Prichett (1998) and Treisman (2000).
} 
instrument working for the public interest. Shah (1998) emphasizes the command and control oriented structure of the bureaucracy in developing countries, especially those that share a common colonial heritage such as India, Kenya, Pakistan and Indonesia. Hiding behind a centralized government system, civil servants as well as elected officials enjoy a high degree of autonomy from public pressure.

The public perception of government may also play an important role in making the bureaucracy free from popular control. According to the cultural theories of institutions, societies hold beliefs and ideas that shape the quality of government. Some cultures may be more prone to an interventionist government structure as compared to other cultures which emphasize individualism and entrepreneurship. Following Webers hypothesis on religion, Grier (1997) and La Porta et al (1998) provide some evidence on why "hierarchical" religions (Catholicism and the Orthodox Christian Church) may exhibit inferior government performance. The argument is that in hierarchical societies the public sector does not need to justify its existence as a service provider, because people generally view the public sector as a position to control rent sources and to exploit state authority for personal gain. Islamic countries fall into this category for a different reason. In Islamic countries, fatalism contributes to lack of citizen activism for better democratic accountability, giving the autocratic rulers a free hand in self-enrichment.

However, one should also mention that cultural explanations of institutions also have a political element. To the extent that culture is shaped by politics, cultural determinants of governance are endogenous, even in the short term. The radical transformation of Japanese society in the 19th century is a perfect example of how the political will of the rulers could change a xenophobic culture and make it open to the rest of the world. Similar examples can be found in China and Catholic Europe.

In this context, decentralization can play an important role in curbing corruption, if the political and institutional environment permits. Decentralization destroys the barrier between citizens and centralized governments by encouraging citizen participation in government decision making, provided that the society possesses basic political and civil freedoms to express opinions. In smaller communities, individuals can find more opportunities to monitor the functioning of local governments and to take action more effectively and promptly, if necessary. As governments come closer to the people they are intended to serve, the civil service re-orients itself towards a service-oriented system to satisfy the basic needs of the society. Armed with strong judicial and political control mechanisms, decentralization may change the social and bureaucratic culture and incentives creating a less isolated thus more accountable civil service. Whether these relationships hold in practice remains an unsettled empirical question. 


\section{THE MODEL AND VARIABLES}

\subsection{Dependent Variable: Corruption}

Corruption is a broad concept covering a wide range of phenomena. It ranges from petty corruption in the form of tips and speed money to grand corruption. The available data on corruption reflect this heterogeneity. Some institutions collect data on irregular payments in the public service, whereas others try to capture corruption in the higher levels of government. Risk rating services, such as Political Risk Services and the Economic Intelligence Unit, typically rely on panel of experts who rate countries using a defined set of criteria. Other organizations, such as the World Economic Forum and the Institute for Management Development, rely on surveys of citizens and entrepreneurs.

A common concern with corruption indicators is that they can be inconsistent or unreliable, or affected by the biases of the observer. A country rated high by one agency or panel of experts may be rated lower by another. One solution is to aggregate indicators from several resources into an average or composite index - a poll of polls. This is the approach that Transparency International uses for its Corruption Perceptions Index (CPI). ${ }^{8}$ To derive this index, TI collects data on corruption from a number of other sources, ${ }^{9}$ standardizes them, and calculates the simple average by assigning equal weights. The assessment also combines data from a few past years to reduce abrupt variations in scoring.

The reliability of each figure is improved by including only countries that have been included into three polls at minimum. An indicator for the overall reliability of the index can be drawn from the high correlation between the sources (see Appendix A). Standardization of the index ensures that the inclusion of a source consisting of a certain subset of countries should not change the mean and standard deviation of this subset of countries in the CPI. The reason is that the aim of each source is to assess countries relative to each other, and not relative to countries not included in the source. This includes the idea that a country must not be punished for being compared with a subset of relatively uncorrupt countries, nor rewarded for being compared with a subset of relatively corrupt countries.

\subsection{Independent Variables:}

6.2.1. The Role of the State in the Economy

We use a variety of measures to capture different aspects of the state:

\footnotetext{
${ }^{8}$ For details see http://www.transparency.org/surveys/index.html

${ }^{9}$ Of these, five are for business executives of international or business companies, two by the relevant organizations staff, one of employees of multinational forums and institutions, and one of embassies and chambers of commerce.
} 
- Size of Government: is proxied by public investment as a share of GDP, including investment by public enterprises, local authorities and consolidated central government.

- Tax System: Efficiency and equality of tax system, tax rates, enforcement of tax regulations, and the tax system as an incentive mechanism are used. Our measure comes from the 1997 World Development Report, which examines the burden of tax regulations and high taxes. This information is used to measure the overall quality of tax management.

- Openness of the Economy: is shown by restrictions on foreign trade, foreign exchange mechanism, foreign investment and capital markets. We use a measure from the Fraser Institute, which compares the actual size of trade sector compared to the expected size.

- Structure of the Economy and Markets: are proxied by production and allocation of resources via government mandates rather than private market (price controls, banking sector, state ownership of enterprises, competitive environment. A composite index is formed by using data from the Fraser Institute on state ownership of enterprises, price controls, and interest rate controls.

All variables are re-scaled such that high numbers are associated with more government involvement in the economy.

\subsubsection{Institutions of Accountability}

- Internal Control: A survey question from the World Development Report 1997 reflects access to other officials or to superiors to get the correct treatment.

- Judiciary: Several indices are available to measure the effectiveness of the judiciary. However, most of them, given the way they are measured, have elements endogenous with corruption. We use an index from the Fraser Institute, which is the least susceptible to simultaneity bias.

- Democratic Institutions: Since it is almost impossible to make a distinction between political institutions and civil society, we combine these two variables under one title: institutions of democracy. A composite measure for democratic accountability provided is constructed using three indices of the Freedom House. These indices are political rights, civil rights, and freedom of the media.

All variables are re-scaled such that high numbers are associated with more effective institutions. 


\subsubsection{Social and Bureaucratic Culture and Incentives}

We analyze the bureaucratic culture and incentives under four categories:

- Attitude of the Bureaucracy towards Society and Business

- Predictability of Laws and Policies

- Effective Public Service Delivery

- Perception of the State by the Society

For the first category we use a rating from the Political Risk Services, which measures the attitude of the state towards private investment. For the next two categories we use two survey questions from the 1997 World Development Report: governments adherence to announced policies and public perception of government as an effective public service provider. Assuming that societies with more "hierarchical" religions, such as Catholicism, Orthodoxy, Islam, are more inclined to have a heavy-handed bureaucracy, we use the Protestant population in a country as an indicator of the perception of the state as a tool for public service. This index is rescaled such that low numbers are associated with a more service-oriented bureaucracy.

An additional measure related to bureaucratic culture and incentives is the colonial past. To capture the colonial past of a country we use a dummy variable that is equal to one if country was ever a colony in the last two centuries.

\subsubsection{Localization/ decentralization}

For decentralization two measures are commonly used in the literature. One is the level of sub-national government expenditures. The other one is the ratio of employment in non-central government administration to general civilian government employment. In this study we use the second measure. This is not only highly correlated with subnational government expenditures $(r=0.67)$, but also covers more countries. Schiavo-Campo et. al. (1997) argue that this variable may perform better in terms of capturing decentralization rather than deconcentration (the geographical dispersal of central government entities without changing their lines of ultimate authority and sources of finance): "He who pays the piper calls the tune".

\subsection{Other Factors}

Finally, some control variables are included in the model. One is the heterogeneity within a country. Shleifer and Vishny (1993), and Tanzi (1994) 
suggest that countries where the population consists of several different ethnic groups create a fertile ground for bribery, nepotism, extortion, and theft by undermining the public trust towards institutions and creating safe heavens within various cliques (see also Mauro, 1995). Our measure for ethnic heterogeneity is the probability that two randomly selected individuals in a country will belong to different ethno-linguistic groups.

Many observers have argued that low government wages in the public service is a major determinant of corruption. Unfortunately data on the ratio of government pay to wages in the manufacturing sector covers very few countries (Van Rickeghem and Weder, 1997, use a sample of 22 countries). Therefore, we use the ratio of government wages relative to GDP per capita.

Social and institutional development may have a significant effect on corruption, independent of the institutions of accountability. A common procedure in the literature is to measure the level of development either by the level of income per capita or the average years of total schooling or both. In this study we try to capture the level of development of the society and institutions by Human Development Index of the United Nations. This index consists of three components: life expectancy, educational attainment and incomes. The major advantage of this index is that it provides a more comprehensive picture of development than income or schooling does.

\section{FORMATION OF COMPOSITE INDICES TO OVERCOME MULTICOLLINEARITY}

Available indicators on the structure of the economy, institutions of democracy, and the bureaucratic culture are collinear (see Appendix D). The application of ridge regression can be used to overcome this collinearity, yet a meaningful economic variables bias. Shah $(1988,1989)$ advocates the use of canonical analysis to form composite indices of collinear variables to overcome multicollinearity. The canonical analysis is preferable to principal component analysis, because the latter technique attempts to maximize the explained variance in these variables, ignoring correlation with the dependent variable. Canonical analysis, on the other hand, forms

linear combinations of original variables in such a way that the resulting composite indexes are maximally correlated with the dependent variable. We use canonical analysis to form composite indices of competitive market structure (based upon data for state owned enterprises, state ownership of banks and price controls), democratic institutions (comprising political rights, civil rights and free media variables) and bureaucratic culture 
(by combining state as a helping hand, credibility of announced policies, efficiency in service delivery and informed and demanding citizenry based upon percent Protestant population). The formation of these composite indices helped us to retain the richness of a large data set while overcoming multicollinearity problems in econometric estimation.

\section{ECONOMETRIC RESULTS ON THE CAUSES OF CORRUPTION}

Since reliability of corruption indices is our main concern, we weight observations by their standard deviation in our regression analysis. These standard deviations published by the Transparency International measure the dispersion of corruption ratings for each country across different polls. Although the White test rejects the existence of heterogeneity, we still use White-corrected standard errors to address country specific characteristics. The estimated model is presented in Table 1 .

Table 1 shows that lack of openness of the economy is significantly related to corruption, whereas public sector size is insignificant and contrary to our a priori expectations has a negative sign. Complexity of the tax system also contributes to corruption (significant at the 10 percent level only). The lack of competitive market structure is identified as a significant source of corruption. Weakness in bureaucratic controls lessens the incidence of corruption although this coefficient is insignificant. This confirms the common perceptions that rigidity of internal controls are not effective to curb corruption. Judicial fairness, on the other hand, has the expected sign but is insignificant. We use different measures for this variable, but the result did not change. An explanation may be that the role of judiciary is secondary to more fundamental drivers for corruption, such as citizenvoter accountability as suggested by strongly significant negative coefficient of democratic institutions. This result possibly suggests that democratic rights and institutions are preconditions for an effective judiciary. Democracy and a free media seem to be very effective deterrent factors against corruption.

It is also interesting to see that variables related to the bureaucratic culture and incentives perform quite well. Decentralization has a negative and significant impact on corruption, whereas lack of service-orientation in bureaucratic culture has a corrupting influence on the public sector. Colonial past has a significantly positive effect on corruption; it increases the rate of corruption by almost 9 points. Colonial past captures command and control habits and institutions and the divisive nature of the society 
left behind by colonial masters. Our control variables, government pay and social development levels have expected signs but are insignificant.

\subsection{Ranking of the Key Factors}

Regression results show that the key determinants of corruption are centralized government structures, bureaucratic elitism fueled by colonial history, weak political and civic institutions, government intervention in the economy, and being closed to international markets. We look at the impact of a one standard deviation change in these variables on corruption in

column (2) Table 1. It turns out that a move from commandand-control culture to service-oriented culture at a magnitude of one standard deviation may decrease corruption by over 17 percent. Civic institutions may also play an important role in anticorruption efforts (16 percent). Among other significant variables, openness of the economy is in third place with 10 percent, market economies with 7 percent, and decentralization with 4 percent.

\subsection{Causes of Corruption in Developing Countries}

Next, we examine the causes of corruption based upon a developing countries sample in Table 2. Although our sample size is small $(n=20)$, we are able to identify some key factors. Openness of the economy, democracy, and bureaucratic culture are the significant factors. The importance of having a colonial past, in particular, does not have a great impact on corruption within developing countries. One reason for this result is that all developing countries in our sample have a colonial past in general. The fact that the structure of the economy and decentralization lose their significance in our restricted sample suggests that more fundamental considerations such as democratic institutions, rule of law and bureaucratic culture have dominant influences in developing countries.

\subsection{Corruption and Decentralization}

In our previous regressions we have found that decentralization reduces corruption in government. However, one can argue that decentralization may not be successful unless it is supported by participation of local communities in policy-making progress through local elections or federalist government structures. Ideally we would prefer to divide countries into two groups according to the existence or absence of local elections. However, only one country (Senegal) in our sample does not organize local elections. So, the coefficient of the decentralization variable also represents the effect of decentralization with local participation. 
TABLE 1.

Causes of Corruption: Full Specification

\begin{tabular}{|c|c|c|c|c|}
\hline & $\begin{array}{c}\text { WLS } \\
\text { Full Specification }\end{array}$ & $\begin{array}{c}\text { Effect of One Standard } \\
\text { Deviation Change on } \\
\text { Corruption } \\
(\% \text { Change Around the Mean })\end{array}$ & $\begin{array}{c}\text { Rank of } \\
\text { Importance }\end{array}$ & $\begin{array}{c}\text { Rank of Importance } \\
\text { (among significant } \\
\text { variables) }\end{array}$ \\
\hline Government size & $\begin{array}{l}-0.1213 \\
(-0.37)\end{array}$ & -1.15 & 12 & \\
\hline $\begin{array}{l}\text { Complexity of Tax } \\
\text { System }\end{array}$ & $\begin{array}{l}0.2900 \\
(1.51)\end{array}$ & 5.71 & 6 & \\
\hline $\begin{array}{l}\text { Degree of closed } \\
\text { economy }\end{array}$ & $\begin{array}{c}0.3206^{* * *} \\
(3.89)\end{array}$ & 10.37 & 3 & 3 \\
\hline $\begin{array}{l}\text { Lack of competitive } \\
\text { market structure }\end{array}$ & $\begin{array}{c}0.1320^{* *} \\
(2.63)\end{array}$ & 7.15 & 5 & \\
\hline $\begin{array}{l}\text { Laxity of bureaucratic } \\
\text { controls }\end{array}$ & $\begin{array}{l}-0.1138 \\
(-1.01)\end{array}$ & -2.00 & 11 & 5 \\
\hline Judicial fairness & $\begin{array}{l}-0.0355 \\
(-0.26)\end{array}$ & -1.09 & 13 & \\
\hline Democratic Institutions & $\begin{array}{c}-0.2571^{* * *} \\
(-4.27)\end{array}$ & -15.54 & 2 & 2 \\
\hline Decentralization & $\begin{array}{c}-0.1722^{*} \\
(-2.02)\end{array}$ & -4.20 & 8 & 6 \\
\hline $\begin{array}{l}\text { Lack of service } \\
\text { orientation in } \\
\text { bureaucratic culture }\end{array}$ & $\begin{array}{c}0.3324^{* * *} \\
(3.54)\end{array}$ & 17.27 & 1 & 1 \\
\hline Colonial Past & $\begin{array}{c}8.8867^{* *} \\
(2.58)\end{array}$ & 8.23 & 4 & 4 \\
\hline Ethnic Heterogeneity & $\begin{array}{l}0.0387 \\
(0.79)\end{array}$ & 2.46 & 10 & \\
\hline Government Pay & $\begin{array}{l}-0.8768 \\
(-1.29)\end{array}$ & -4.35 & 7 & \\
\hline Social Development & $\begin{array}{c}0.0712 \\
(0.36)\end{array}$ & 2.50 & 9 & \\
\hline Sample Size & 30 & & & \\
\hline Adj. R sq. & 0.9870 & & & \\
\hline
\end{tabular}

The dependent variable is the corruption index of TI where a higher value of the index corresponds to more corruption. The inverse of standard deviation of corruption index is used in the weighted LS regression. Errors are White-Heterocedasticity consistent

t-statistics are in parenthesis — standard errors are White-corrected for heterogeneity. ${ }^{* * *}$ significant at $p<0.01{ }^{* *}$ significant at $p<0.05^{*}$ significant at $p<0.10$ 
TABLE 2.

Corruption in Developing Countries

\begin{tabular}{|c|c|}
\hline & Developing Country Sample \\
\hline Government size & $\begin{array}{l}-0.0938 \\
(-0.26)\end{array}$ \\
\hline $\begin{array}{l}\text { Complexity of Tax } \\
\text { System }\end{array}$ & $\begin{array}{l}-0.0346 \\
(-0.09)\end{array}$ \\
\hline $\begin{array}{l}\text { Degree of closed } \\
\text { economy }\end{array}$ & $\begin{array}{c}0.3911^{* * *} \\
(4.63)\end{array}$ \\
\hline $\begin{array}{l}\text { Lack of competitive } \\
\text { market structure }\end{array}$ & $\begin{array}{l}-0.0217 \\
(-0.17)\end{array}$ \\
\hline $\begin{array}{l}\text { Laxity of bureaucratic } \\
\text { controls }\end{array}$ & $\begin{array}{l}-0.1220 \\
(-0.67)\end{array}$ \\
\hline Judicial fairness & $\begin{array}{l}0.0752 \\
(0.52)\end{array}$ \\
\hline Democratic Institutions & $\begin{array}{c}-0.1985^{* *} \\
(-2.63)\end{array}$ \\
\hline Decentralization & $\begin{array}{l}-0.1773 \\
(-1.14)\end{array}$ \\
\hline $\begin{array}{l}\text { Lack of service } \\
\text { orientation in } \\
\text { bureaucratic culture }\end{array}$ & $\begin{array}{c}0.2918^{* * *} \\
(3.76) \\
\end{array}$ \\
\hline Colonial Past & $\begin{array}{l}2.4636 \\
(0.60)\end{array}$ \\
\hline Ethnic Heterogeneity & $\begin{array}{l}0.0778 \\
(1.02) \\
\end{array}$ \\
\hline Government Pay & $\begin{array}{l}-1.3091 \\
(-1.39) \\
\end{array}$ \\
\hline Social Development & $\begin{array}{l}-0.0029 \\
(-0.01)\end{array}$ \\
\hline Sample Size & 20 \\
\hline Adj. R sq. & 0.9658 \\
\hline
\end{tabular}

The dependent variable is corruption index of TI where higher value of the index corresponds to more corruption. Inverse of standard deviation of corruption index is used in the weighted LS regression. Errors are White-Heterocedasticity consistent. t-statistics are in parenthesis - standard errors are Whitecorrected for heterogeneity. ${ }^{* * *}$ significant at $p<0.01{ }^{* *}$ significant at $p<0.05^{*}$ significant at $p<0.10$

Next, we ask ourselves whether the relationship between decentralization and corruption differs between federal and unitary states. We divide our 
TABLE 3.

Decentralization and Corruption: Unitary vs. Federal States

\begin{tabular}{|c|c|}
\hline & All countries \\
\hline Government size & $\begin{array}{l}0.0458 \\
(0.15)\end{array}$ \\
\hline $\begin{array}{l}\text { Complexity of Tax } \\
\text { System }\end{array}$ & $\begin{array}{l}0.3030 \\
(1.50)\end{array}$ \\
\hline $\begin{array}{l}\text { Degree of closed } \\
\text { economy }\end{array}$ & $\begin{array}{c}0.3217^{* * *} \\
(3.60)\end{array}$ \\
\hline $\begin{array}{l}\text { Lack of competitive } \\
\text { market structure }\end{array}$ & $\begin{array}{c}0.1244^{* *} \\
(2.49)\end{array}$ \\
\hline $\begin{array}{l}\text { Laxity of bureaucratic } \\
\text { controls }\end{array}$ & $\begin{array}{l}-0.1521 \\
(-1.13)\end{array}$ \\
\hline Judicial fairness & $\begin{array}{l}-0.0135 \\
(-0.09)\end{array}$ \\
\hline Democratic Institutions & $\begin{array}{c}-0.3065^{* * *} \\
(-5.05)\end{array}$ \\
\hline $\begin{array}{l}\text { Decentralization in } \\
\text { Unitary States }\end{array}$ & $\begin{array}{c}-0.4758^{* *} \\
(-2.28)\end{array}$ \\
\hline $\begin{array}{l}\text { Decentralization in } \\
\text { Federal States }\end{array}$ & $\begin{array}{c}-0.2260^{* *} \\
(-2.51)\end{array}$ \\
\hline $\begin{array}{l}\text { Lack of service orientation } \\
\text { in bureaucratic culture }\end{array}$ & $\begin{array}{c}0.3219^{* * *} \\
(3.45)\end{array}$ \\
\hline Colonial Past & $\begin{array}{c}9.7196^{* *} \\
(2.58) \\
\end{array}$ \\
\hline Ethnic Heterogeneity & $\begin{array}{c}0.0370 \\
(0.83) \\
\end{array}$ \\
\hline Government Pay & $\begin{array}{l}-0.8758 \\
(-1.22)\end{array}$ \\
\hline Social Development & $\begin{array}{l}0.1065 \\
(0.54)\end{array}$ \\
\hline Sample Size & 30 \\
\hline Adj. R sq. & 0.9873 \\
\hline
\end{tabular}

The dependent variable is corruption index of TI where higher value of the index corresponds to more corruption. Inverse of standard deviation of corruption index is used in the weighted LS regression. Errors are White-Heteroskedasticity consistent t-statistics are in parenthesis - standard errors are Whitecorrected for heterogeneity. ${ }^{* * *}$ significant at $p<0.01^{* *}$ significant at $p<0.05^{*}$ significant at $p<0.10$

sample into two groups and look at the coefficient of decentralization in each group. The results are shown in Table 3. Decentralization in unitary states 
has a greater impact on the incidence of corruption. The reason for this may be that, as shown by Huther and Shah (1998), federal states typically have a lower degree of corruption due to competition among governments. We test the equality of coefficients and it is rejected at the 5 percent significance level.

\subsection{Robustness of the Results: Sensitivity Analysis}

Our WLS results show that variables related to bureaucratic culture and incentives - including decentralization and colonial past - are surprisingly significant despite the presence of all other variables included our basic regression. One concern in crosssectional studies on corruption is the robustness of these results to outliers and influential observations. We first repeated our full specification using a robust regression technique (M estimators) and compare the results with our basic findings. We also used an iterative least square estimation technique, which uses absolute residuals of the previous regression as weights in the new regression. Both regressions gave us estimators quite similar to our basic results. This is particularly true for variables that are significant in the basic model.

To further test the robustness of our results, we performed a variation of extreme bounds test (Leamer, 1985) suggested by Levine and Renelt (1992). The purpose of extreme bounds analysis is to assess the sensitivity of results to the model specification. The set of explanatory variables is divided into two subsets representing the variables that should always be included in the regression (I-variables) and the variables that could potentially be included (Z-variables). A separate regression is performed for every combination of $\mathrm{Z}$-variables. It requires that a regressor remains significant at the 5 percent level with the same sign in all regressions. There are no previous studies on which to decide which subset of variables should always be included and which are of potential interest. So, we use the reliability of data as our criteria. The ratings and data used to measure some of our variables are quite imperfect, so they may not capture the potential effect of these variables. Our Z-variables are tax system, internal control, ethnic heterogeneity, social development, and government wage. We perform 31 regressions. Bureaucratic culture remained significant in all regressions, and colonial past slipped over the 5 percent significance level 5 times. However, colonial past failed to pass the test only in some of the models in which social development is excluded. This suggests the negative effect of colonial history on corruption may be less significant in countries that inherit a well-developed and educated society. 


\section{CONCLUSIONS}

This paper has attempted to identify major drivers of corruption in order to isolate the role of centralized decision-making. In a sample of industrial and non-industrial countries, the lack of service orientation in the public sector, weak democratic institutions, economic isolation (closed economy), colonial past, internal bureaucratic controls and centralized decisionmaking are identified as the major causes of corruption. For a sample of non-industrial countries, drivers for corruption are lack of service orientation in the public sector, weak democratic institutions and a closed economy. Decentralization has a greater negative impact on corruption in unitary countries than in federal countries. In conclusion, decentralization

is confirmed here to support greater accountability in the public sector and reduced corruption. 
APPENDIX A

\section{Sources for the 1998 Corruption Perceptions Index}

\begin{tabular}{|c|c|c|c|c|c|c|}
\hline No & Source & Year & Who was Surveyed? & Subject Asked & $\begin{array}{l}\text { Number } \\
\text { of Replies }\end{array}$ & Number of Countries \\
\hline \multirow[b]{2}{*}{1} & \multirow{2}{*}{$\begin{array}{l}\text { Political \& Economic Risk } \\
\text { Consultancy }\end{array}$} & 1997 & \multirow{2}{*}{$\begin{array}{l}\text { Expatriate Business } \\
\text { Executives }\end{array}$} & \multirow{2}{*}{$\begin{array}{l}\text { Extent of Corruption in a way that } \\
\text { detracts from the business environment } \\
\text { for foreign companies }\end{array}$} & \multirow[t]{2}{*}{280} & \multirow[t]{2}{*}{12 Asian countries } \\
\hline & & 1998 & & & & \\
\hline 2 & Gallup International & 1997 & General Public & $\begin{array}{l}\text { Cases of corruption for the following } \\
\text { group of people: politicians, public } \\
\text { officials, policeman, and judges }\end{array}$ & $\begin{array}{c}\text { over } \\
34000\end{array}$ & $\begin{array}{l}44 \text { mostly developed } \\
\text { countries }\end{array}$ \\
\hline \multirow{3}{*}{3} & \multirow{3}{*}{$\begin{array}{l}\text { Institute for Management } \\
\text { Development } \\
\text { (World Competitiveness } \\
\text { Yearbook) }\end{array}$} & 1996 & \multirow{3}{*}{$\begin{array}{l}\text { Business Executives } \\
\text { in Top and Middle } \\
\text { Management }\end{array}$} & \multirow{3}{*}{$\begin{array}{l}\text { Improper practices (such as bribing or } \\
\text { corruption) in the public sphere }\end{array}$} & 3102 & \multirow{3}{*}{$\begin{array}{l}46 \text { mostly developed } \\
\text { countries }\end{array}$} \\
\hline & & 1997 & & & 2515 & \\
\hline & & 1998 & & & 4314 & \\
\hline \multirow{3}{*}{4} & \multirow{3}{*}{$\begin{array}{l}\text { World Economic Forum } \\
\text { (Global } \\
\text { Competitiveness Survey) }\end{array}$} & 1996 & \multirow{3}{*}{ Business Executives } & \multirow{3}{*}{$\begin{array}{l}\text { Irregular, additional payments } \\
\text { connected with import and export } \\
\text { permits, business licenses, exchange } \\
\text { controls, tax assessments, police } \\
\text { protection, or loan application }\end{array}$} & 1537 & $\begin{array}{l}40 \text { developed and } \\
\text { developing countries }\end{array}$ \\
\hline & & 1997 & & & 2778 & $\begin{array}{l}56 \text { developed and } \\
\text { developing countries }\end{array}$ \\
\hline & & 1998 & & & 3500 & $\begin{array}{l}68 \text { developed and } \\
\text { developing countries }\end{array}$ \\
\hline 5 & $\begin{array}{l}\text { Political Risk Services } \\
\text { (International Country } \\
\text { Risk Guide) }\end{array}$ & 1998 & Assessment of Staff & $\begin{array}{l}\text { Assessment of corruption in } \\
\text { Assessment of corruption in } \\
\text { government }\end{array}$ & & $\begin{array}{l}135 \text { developed and } \\
\text { developing countries }\end{array}$ \\
\hline 6 & $\begin{array}{l}\text { World Bank (World } \\
\text { Development Report- } \\
\text { Private Sector Survey) }\end{array}$ & 1997 & Business Executives & $\begin{array}{l}\text { Irregular, additional payments are } \\
\text { common and represent an obstacle } \\
\text { to doing business }\end{array}$ & over 3500 & $\begin{array}{l}73 \text { developed and } \\
\text { developing countries }\end{array}$ \\
\hline 7 & $\begin{array}{l}\text { Economic Intelligence Unit } \\
\text { (Country Risk Service and } \\
\text { Country Forecast) }\end{array}$ & 1998 & Assessment by Staff & $\begin{array}{l}\text { Assessment of pervasiveness of } \\
\text { corruption among politicians } \\
\text { and civil servants }\end{array}$ & & $\begin{array}{l}115 \text { developed and } \\
\text { developing countries }\end{array}$ \\
\hline
\end{tabular}




\section{APPENDIX: B: SAMPLE SPACE}

$\begin{array}{lll} & \text { (Developing Countries in Bold) } \\ \text { 1. Austria } & \text { 11. Ghana } & \text { 21. Senegal } \\ \text { 2. Bolivia } & \text { 12. Hungary } & \text { 22. South Africa } \\ \text { 3. Cameroon } & \text { 13. India } & \text { 23. Switzerland } \\ \text { 4. Canada } & \text { 14. Ireland } & \text { 24. Tanzania } \\ \text { 5. Columbia } & \text { 15. Italy } & \text { 25. Turkey } \\ \text { 6. Cote Elvoire } & \text { 16. Jordan } & \text { 26. Uganda } \\ \text { 7. Ecuador } & \text { 17. Kenya } & \text { 27. United Kingdom } \\ \text { 8. Estonia } & \text { 18. Malaysia } & \text { 28. United States of America } \\ \text { 9. France } & \text { 19. Morocco } & \text { 29. Venezuela } \\ \text { 10. Germany } & \text { 20. Portugal } & \text { 30. Zambia }\end{array}$

APPENDIX: C: DATA SOURCES AND DESCRIPTIONS

\begin{tabular}{|c|c|c|}
\hline \multicolumn{3}{|l|}{ Corruption } \\
\hline Corruption & $\begin{array}{l}1998 \text { Corruption Perceptions Index of Transparency International. The Index includes data } \\
\text { from the Economist Intelligence Unit, Gallup International, the Institute for Management } \\
\text { Development, the Political and Economic Risk Consultancy, the Political Risk Services, } \\
\text { World Development Report, and the World Economic Forum. Some of these sources are } \\
\text { based on poll of experts, some others on investor and public surveys. The Index combines } \\
\text { assessments from the past three years to reduce abrupt variations in scoring. None of these } \\
\text { sources differentiate between special forms of corruption, such as political or administrative. } \\
\text { So, they aim to measure the same phenomenon. All indices are strongly correlated with each } \\
\text { other. The reliability is further improved by including only countries that have been included } \\
\text { into three polls at minimum. Simple average method is used to aggregate the data. }\end{array}$ & Transparency International \\
\hline \multicolumn{3}{|c|}{ Size of Government } \\
\hline \multicolumn{2}{|c|}{$\begin{array}{l}\text { Size of Government Ratio of nominal public domestic investment (fixed capital formation) } \\
\text { to nominal GDP. }\end{array}$} & $\begin{array}{l}\text { World Development Report } \\
1997 \text { and OECD }\end{array}$ \\
\hline \multicolumn{3}{|l|}{ Tax System } \\
\hline $\begin{array}{l}\text { Burden of Tax } \\
\text { Regulations }\end{array}$ & "Tax Regulations and/or high taxes are major problem areas" & $\begin{array}{l}\text { World Bank: World Develop- } \\
\text { ment Report } 1997 \text { Q-12G }\end{array}$ \\
\hline \multicolumn{3}{|c|}{ Openness of the Economy } \\
\hline $\begin{array}{l}\text { Restrictions on } \\
\text { International } \\
\text { Trade }\end{array}$ & $\begin{array}{l}\text { An index constructed from the ratio of actual size of trade sector to the expected } \\
\text { size. Regression analysis is used to estimate the expected size of the trade sector } \\
\text { given geographic size, population, and location relative to potential trading partners }\end{array}$ & $\begin{array}{l}\text { Fraser Institute: Economic } \\
\text { Freedom of the World } 1997 \\
\text { Category VI-B.ii }\end{array}$ \\
\hline
\end{tabular}




\begin{tabular}{|c|c|c|}
\hline \multicolumn{3}{|c|}{ Structure of the Economy } \\
\hline \begin{tabular}{|l} 
Government \\
Enterprises and \\
Investment
\end{tabular} & An index based on government enterprises and investment as a proportion of GDP & $\begin{array}{l}\text { Fraser Institute: Economic Freedom } \\
\text { of the World } 1997 \\
\text { Category II-A }\end{array}$ \\
\hline Price Controls & An index based on the extent to which businesses are free to set their own prices & $\begin{array}{l}\text { Fraser Institute: Economic Freedom } \\
\text { of the World } 1997 \\
\text { Category II-B }\end{array}$ \\
\hline $\begin{array}{l}\text { State Ownership } \\
\text { of Banks }\end{array}$ & An index based on the percent of credits issued by privately owned banks & $\begin{array}{l}\text { Fraser Institute: Economic Freedom } \\
\text { of the World } 1997 \text { Category VI-A }\end{array}$ \\
\hline \multicolumn{3}{|c|}{ Formal Institutions } \\
\hline $\begin{array}{l}\text { Internal Control } \\
\text { Mechanism }\end{array}$ & $\begin{array}{l}\text { "If a government agent acts against the rules I can usually go to another officials or } \\
\text { to his superior and get the correct treatment" }\end{array}$ & $\begin{array}{l}\text { World Bank: World Development } \\
\text { Report 1997 Q18 }\end{array}$ \\
\hline Judiciary & $\begin{array}{l}\text { Legal institutions are supportive of rule of law principles and permit access to } \\
\text { non-discriminatory judiciary }\end{array}$ & $\begin{array}{l}\text { Fraser Institute: Economic Freedom } \\
\text { of the World } 1997 \text { Category V-C }\end{array}$ \\
\hline \multicolumn{3}{|c|}{ Institutions of Democracy } \\
\hline Political Rights & Average county scores for the years 1990-99 & $\begin{array}{l}\text { Freedom House: Annual Survey of } \\
\text { Freedom }\end{array}$ \\
\hline Civil Liberties & Average county scores for the years 1990-99 & $\begin{array}{l}\text { Freedom House: Annual Survey of } \\
\text { Freedom }\end{array}$ \\
\hline Press Freedom & Average county scores for the years 1990-99 & Freedom House: Press Freedom 1999 \\
\hline \multicolumn{3}{|c|}{ Decentralization and Bureaucratic Culture } \\
\hline $\begin{array}{l}\text { Investment } \\
\text { Profile }\end{array}$ & $\begin{array}{l}\text { A measure of governments attitude to inward investment as determined by four sub- } \\
\text { components: the risk to operations, taxation, repatriation, and labor costs. }\end{array}$ & $\begin{array}{l}\text { Political Risk Services: International } \\
\text { Country Risk Guide }\end{array}$ \\
\hline $\begin{array}{l}\text { Stick to Announced } \\
\text { Policies }\end{array}$ & dd"Do you expect the government to stick to announced major policies?" & $\begin{array}{l}\text { World Bank: World Development } \\
\text { Report 1997 Q3 }\end{array}$ \\
\hline $\begin{array}{l}\text { Efficiency of Public } \\
\text { Service Delivery }\end{array}$ & c"How would you generally rate the efficiency of government in delivering services?" & $\begin{array}{l}\text { World Bank: World Development } \\
\text { Report 1997 Q25 }\end{array}$ \\
\hline Protestantism & Ratio of protestant population in the country & La Porta et. al. (1998) \\
\hline Colonial Past & $\begin{array}{l}\text { Dummy variable which is equal to one if the country has a colonial past in the last } \\
\text { two centuries and zero otherwise }\end{array}$ & $\begin{array}{l}\text { CIA World Fact, La Porta et.al } \\
\text { (1998), and Encyclopedia Britannica } \\
\text { and the World Handbook of Political } \\
\text { and Social Indicators }\end{array}$ \\
\hline Decentralization & $\begin{array}{l}\text { Ratio of employment in non-central government administration to general civilian } \\
\text { government employment. Non-central government administration encompasses all } \\
\text { government administration employees who are not specifically funded by the central } \\
\text { government. It includes municipalities, as also regional, provincial or state } \\
\text { employment. }\end{array}$ & Schiavo-Campo et.al (1997) \\
\hline Federal Structure & Sub-national elections in state or province level & IMF Government Finance Statictics 1998 \\
\hline \multicolumn{3}{|l|}{ Other } \\
\hline \begin{tabular}{|l} 
Ehnolinguistic \\
Heterogeneity \\
\end{tabular} & $\begin{array}{l}\text { The probability that two randomly selected individuals in a country will belong to } \\
\text { different ethnolinguistic groups }\end{array}$ & La Porta et. al. (1998) \\
\hline Wage/GDP & Average government wages to per capita GDP & Schiavo-Campo et.al (1997) \\
\hline $\begin{array}{l}\text { Social } \\
\text { Development }\end{array}$ & $\begin{array}{l}\text { Human Development Index of the United Nations. The index as crafted by UNDP } \\
\text { includes measures of mortality, education and economic activity. }\end{array}$ & $\begin{array}{l}\text { United Nations Human Development } \\
\text { Report } 1998\end{array}$ \\
\hline
\end{tabular}




\section{APPENDIX: D: COMPOSITE MEASURES}

We present the details on composite measures below:

\begin{tabular}{|l|c|c|c|c|}
\hline STRUCTURE OF THE ECONOMY & SOE & Price Control & State Banks & Corruption \\
\hline State-Owned Enterprises & 1.00 & & & \\
\hline Price Controls & 0.57 & 1.00 & & \\
\hline State Ownership of Banks & 0.43 & 0.60 & 1.00 & \\
\hline Corruption & 0.64 & 0.67 & 0.47 & 1.00 \\
\hline
\end{tabular}

Structure of the Economy $=0.48 *$ SOE $+0.30 *$ Price_Control $+0.22 *$ State_Banks

\begin{tabular}{|l|c|c|c|c|}
\hline INSTITUTIONS OF DEMOCRACY & Pol Rights & Civil Rights & Media & Corruption \\
\hline Political Rights & 1.00 & & & \\
\hline Civil Rights & 0.93 & 1.00 & & \\
\hline Free Media & 0.90 & 0.89 & 1.00 & \\
\hline Corruption & -0.72 & -0.80 & -0.70 & 1.00 \\
\hline
\end{tabular}

Democracy $=-0.15 *$ Pol Rights $+0.98 *$ Civil Rights $+0.17 *$ Media

\begin{tabular}{|l|c|c|c|c|c|}
\hline BUREAUCRATIC CULTURE & $\begin{array}{c}\text { Helping } \\
\text { Hand }\end{array}$ & Policy & $\begin{array}{c}\text { Public } \\
\text { Service }\end{array}$ & Protestant & Corruption \\
\hline State as a Helping Hand & 1.00 & & & & \\
\hline Stick to Announced Policies & 0.32 & 1.00 & & & \\
\hline Efficiency of Public Service Delivery & 0.49 & 0.30 & 1.00 & & \\
\hline Percent of Protestant Population & 0.10 & 0.33 & 0.18 & 1.00 & \\
\hline Corruption & 0.21 & 0.40 & 0.76 & 0.43 & 1.00 \\
\hline
\end{tabular}

Bureaucratic Culture $=0.08 *$ Helping Hand $+0.18 *$ Policy $+0.55 *$ Public Service $+0.19 *$ Protestant

\section{REFERENCES}

Ades, Alberto and Rafael Di Tella, 1997. National Champions and Corruption: Some Unpleasant Interventionist Arithmetic. The Economic Journal 107, 1023-1042.

Ahlin, Christian, 2000. Corruption, Aggregate Economic Activity and Political Organization. University of Chicago, processed.

Bardhan, Pranab and Dilip Mookherjee, 2000. Corruption and Decentralization of Infrastructure Delivery in Developing Countries. Institute for Economic Development Working Paper No. 104 , Massachusetts: Boston University.

Becker, Gary S., 1968. Crime and Punishment: An Economic Approach. Journal of Political Economy 76(2), 169-217.

Becker, Gary S. and George J. Stigler, 1974. Law Enforcement, Malfeasance, and Compensation of Enforcers. Journal of Legal Studies 3, 1-18.

Blanchard, Olivier and Andrei Shleifer, 2000. Federalism with and without Political Centralization: China verses Russia. NBER Working Paper 7616, Cambridge, Mass.: National Bureau of Economic Research. 
Boadway, R., Roberts, S., and Shah, A., 2000. Fiscal Federalism Dimensions of Tax Reform in Developing Countries, in Perry, G., Whalley, J., and McMahon, G. (eds.) Fiscal Reform and Structural Change in Developing Countries, Vol. 1. New York: St. Martins Press.

Carbonara, Emanuela, 2000. Corruption and Decentralization, Dipartimento di Scienze Economich, Working Paper No. 342/83, Universita degli Studi di Bologna.

Crook, Richard and James Manor, 2000. Democratic Decentralization, OED Working Paper Series No. 11, Washington, DC: World Bank.

Evans, Peter and James Rauch, 1997. Bureaucratic Structure and Economic Performance in Less Developed Countries, IRIS Working Paper 175, Maryland: IRIS.

Fiszbein, Ariel, 1997. The Emergence of Local Capacity: Lessons from Colombia. World Development 25(7), 1029-1043.

Goel, Rajeev K. and Michael A. Nelson, 1998. Corruption and Government Size: A Disaggregated Analysis. Public Choice 97(1-2), 107-120.

Grier, Robin, 1997. The Effect of Religion on Economic Development: A Cross National Study of 63 Former Colonies. Kyklos 1, 47-62.

Huther, Jeff and Anwar Shah, 1998. A Simple Measure of Good Governance and Its Application to the Debate on Fiscal Decentralization, World Bank Policy Research Working Paper Series No. 1498, Washington, DC: World Bank.

Huther, Jeff and Anwar Shah, 2000. Anti-corruption Programs and Policies: A Framework for Evaluation, World Bank Policy Research Working Paper Series No. 2501, Washington, DC: World Bank.

Isham, Jonathan, Daniel Kaufmann, and Lant H. Pritchett, 1998. Civil Liberties, Democracy, and the Performance of Government Projects. The World Bank Economic Review 11(2), 219-242.

Johnson, Simon, Daniel Kaufmann, and Pablo Zoido-Lobaton, 1998. Regulatory Discretion and the Unofficial Economy. American Economic Review 88(2), 387-92.

Klitgaard, Robert E., 1988. Controlling Corruption. Berkeley: University of California Press.

Kuncoro, Ari, 2000. The Impact of Licensing Decentralization on Firm Location Choice: The Case of Indonesia, University of Indonesia, processed.

La Porta, Rafael, Florencio Lopez-de-Silanes, Andrei Shleifer, and Robert Vishny, 1998. The Quality of Government, NBER Working Paper 6727, Cambridge, Massachusetts: National Bureau of Economic Research.

Laffont, Jean-Jacque, 1990. Analysis of Hidden Gaming in a Three Level Hierarchy. Journal of Law, Economics, and Organization 6(2), 301-324.

Lambsdorff, Johann, 1999. Corruption in Empirical Research — A Review, Transparency International, processed.

Leamer, Edward, 1985. Sensitivity Analysis Would Help. American Economic Review $\mathbf{5 7 ( 3 ) , 3 0 8 - 3 1 3 . ~}$

Levine, Ross and David Renelt, 1992. A Sensitivity Analysis of Cross-Country Growth Regressions. American Economic Review 82(4), 942-963.

Leff, Hathaniel, 1964. Economic Development Through Bureaucratic Corruption. American Behavioral Scientist 8(3), 8-14.

Mauro, Paolo, 1995. Corruption and Growth. Quarterly Journal of Economics 110(3), 681-712. 
Olowu, Dele, 1993. Governmental Corruption and Africa's Democratization Efforts. Journal of Corruption and Reform 7(3), 227-236.

Prudhomme, Remy, 1995. The Dangers of Decentralization. World Bank Research Observer 10(2), 201-220.

Rose-Ackerman, Susan, 1978. Corruption: A Study in Political Economy. New York: Academic Press.

Schiavo-Campo, Salvatore, Giulio de Tommaso, and Amitabha Mukherjee, 1997. An International Statistical Survey of Government Employment and Wages, World Bank Policy Research Working Paper 1806, Washington, DC: The World Bank.

Schleifer, Andrei and Robert Vishny, 1993. Corruption. Quarterly Journal of Economics 108(3), 599-617.

Seabright, Paul, 1996. Accountability and Decentralisation in Government: An Incomplete Contracts Model. European Economic Review 40(1), 61-89.

Shah, Anwar and Mark Schacter, 2004. Combating Corruption: Look Before You Leap, Finance and Development, December 2004: 40-43.

Shah, Anwar, Theresa Thompson, and Heng-fu Zou, 2004. The Impact of Decentralization on Service Delivery, Corruption, Fiscal Management and Growth in Developing and Emerging Market Economies: A Synthesis of Empirical Evidence, CESifo Dice Report. A Quarterly Journal for Institutional Comparisons Vol. 2 (Spring), 10-14.

Shah, Anwar, 2003. Fiscal Decentralization in Transition Economies and Developing Countries.Progress, Problems and the Promise. In Raoul Blindenbacher and Arnold Koller, editors, Federlaism in a Changing World: Learning From Each Other. Pp. 432-460. Montreal and Kingston: McGill-Queens University Press

Shah, Anwar, 1998. Balance, Accountability, and Responsiveness: Lessons about Decentralization. World Bank Policy Research Working Paper Series 2021, Washington, DC: World Bank.

Shah, Anwar, 1994. The Reform of Intergovernmental Fiscal Relations in Developing and Emerging Market Economies, World Bank: Washington, DC

Shah, Anwar, 1994. Perspectives on the Design of Intergovernmental Fiscal Relations in Developing/Transition Economies, in Gupta, Knight, Waxman, and Wen (eds.) Intergovernmental Fiscal Relations and Macroeconomic Management in Large Countries.Proceedings of an EDI (World Bank) Seminar, 1991. New Delhi: Allied Publisher Limited.

Shah, Anwar, 1989. A Capitalization Approach to Fiscal Incidence at the Local Level. Land Economics 65(4), 359-375.

Shah, Anwar, 1988. Capitalization and the Theory of Local Public Finance: An Interpretative Essay. Journal of Economic Surveys 2(3), 209-43.

Tanzi, Vito, 1994. Corruption, Government Activities, and Markets, IMF Working Paper 94/99, Washington: International Monetary Fund.

Tanzi, Vito, 1995. Fiscal Federalism and Decentralization: A Review of Some Efficiency and Macroeconomic Aspects. Annual World Bank Conference on Development Economics, 295-316.

Tirole, Jean, 1986. Hierarchies and Bureaucracies: On the Role of Collusion in Organizations. Journal of Law, Economics, and Organization 2(2), 181-214.

Treisman, Daniel, 2000. The Causes of Corruption: A Cross National Study. Journal of Public Economics, 76(3), 399-457. 
Treisman, Daniel, 1999. Decentralization and Corruption: Why are Federal States Perceived to be More Corrupt, Paper prepared for the presentation at the Annual Meeting of the American Political Science Association, Atlanta, September 1999.

Van Rijckeghem, Caroline and Beatrice Weder, 1997. Corruption and Rate of Temptation: Do Low Wages in the Civil Service Cause Corruption?, IMF Working Paper 97/73, Washington, DC: International Monetary Fund.

Wade, Robert, 1997. How Infrastructure Agencies Motivate Staff: Canal Irrigation in India and the Republic of Korea, Economic Development Institute (EDI) Learning Resources Series, Washington, DC: World Bank.

Wildasin, David, 1995. Comment on 'Fiscal Federalism and Decentralization: A Review of Some Efficiency and Macroeconomic Aspects'. Annual World Bank Conference on Development Economics, 323-328.

World Development Report, 1997. The State in a Changing World. Washington, DC: The World Bank. 